\section{造船·重工業分野へのニュー 溶接·接合プロセスの適用 ${ }^{*}$}

北側 彰 ${ }^{* *}$ 浅井
牧野 吉延
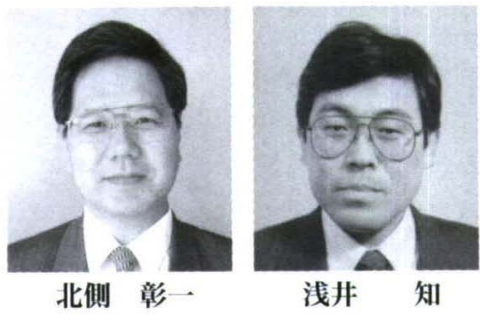

浅井

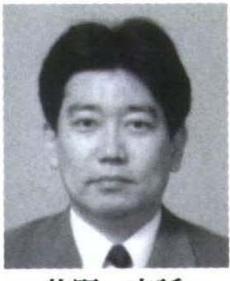

牧野吉延

\begin{abstract}
Application of New Welding and Joining Processes to Shipbuilding and Heavy Industries *
by KITAGAWA Akikazu**, ASAI Satoru ${ }^{* * *}$ and MAKINO Yoshinobu ${ }^{* \star *}$
\end{abstract}

キーワード レーザ, レーザハイブリット, FSW, 造船, 発電プラント

\section{1.はじめに}

造船・重工業分野で使用されている接合技術は主にア 一ク溶接技術であり,これらは19世紀末から20世紀初頭 にかけて発明されたものである. その後アーク溶接技術 そのものは抄拧よそ1970年代に完成の領域に達し，1980 年代以降はプロセス制御技術や CAD, CAM, CIM とい ったコンピュー夕を駆使した高生産性技術の開発へその 重点はシフトしていった.

一方，20世紀後半になり開発された新しい溶接施工法 にレーザ溶接, レーザハイブリッド溶接, 摩擦㩭找溶接 （FSW）および界面接合法がある。これらはちょうどアー ク溶接の摇籃期と同様の状況にあると考え，10から 20 年 後にはこれらの溶接法が至極当然の施工法となっている ことも予想される.これらの溶接法の特徵としては, 必 ずしも開先を必要とせず, 熱影響が少なく, 低歪, 低入 熱な溶接が可能であることで，これらを利用することで， 高精度, 高剛性, 軽量化, 異材構造などの新しい構造化 技術を提供できると考えられる。

ここでは，これらの技術革新をもたらすと期待される ニュー溶接・接合プロセスの造船・重工分野での適用の 現状と今後の展開を構造化技術の視点から述べる.

\section{2. 造船分野におけるニュー溶接・接合 プロセスの適用}

\section{1 レーザ溶接}

レーザ発振はメイマンにより1964年に実現され，その 直後から,レーザ溶接の適用検討がはじめられ心臟ペー スメーカの溶接などでは1970年代初頭に実用化されてい

\section{*原稿受付 平成14年 11 月6日}

**正員 日立造船㧣 Member, HITACHI ZOUSEN CORPORATION

***正員 珠東芝 Member, TOSHIBA CORPORATION
る1”。しかしながら, 造船分野で用いられる厚板を溶接す るには少なくとも $10 \mathrm{~kW}$ の出力が必要であり, 溶接研究 には1980年代初頭に販売された米国 AVCO 社の $15 \mathrm{kWCO}_{2}$ レーザの出現を待っ必要があった，これには, 大出力レ 一ザ装置の開発には多額の費用が必要なこともあり, 米 ソ超大国の軍需関係機関でしか開発できなかったことと, 技術的には連続波の大出力レーザを安定に取り出すこと のできる空力空 (Aero dynamic window) が未開発であっ たことも関係していると思われる. 当時の研究開発の最 先端はもちろん米国海軍研究所であり, 日本に扔いても 重工・鉄鋼会社が共同でAVCO 社へサンプル実験を依頼 するなどレーザ溶接の基礎性能調查を実施しているリ。 そ の後, 1990年代にユナイテッドテクノロジー社が $45 \mathrm{~kW}$ の大 出力レーザを販売し, TWI, フランス溶接研究所, AMPI （日本）などで大出力 $\mathrm{CO}_{2}$ レーザ溶接の基碟技術確立が四ら れた.

TWI やフランス溶接研究所での研究開発は欧州統合準 備期間と符合し，欧州全体の産業競争力を高めるため実 施された欧州プロジェクトでは, 基礎研究開発から実用 までを一貫して見据えた研究開発が立案され多額の予算

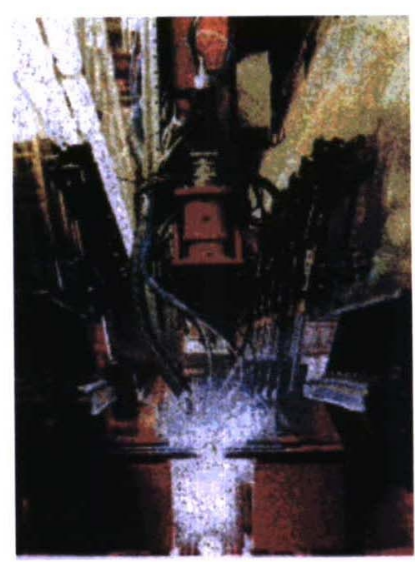

図1フフィンカンツェリ造船所での板継溶接 
が継続的に注入された。この成果として, 欧州船級協会 (フランス，ノルウエー, ドイッ，イギリスおよびイタリ ア）は1997に Guidelines for the approval of $\mathrm{CO}_{2}$-Laser Welding を作成し，レーザ溶接を造船分野で実用化させ る端緒を開いた 2 .

これらのプロジェクトの成果として，図 1 に示すフィ ンカンツエリ造船所（イタリア）での板継溶接 ${ }^{3)}$, マイヤ 一造船所（ドイッ）でのサンドイッチパネル製造（図２） がある4).

フィンカンツエリ造船所が採用した板継溶接は構造化 技術という点からは新しい展開ではないが, 世界の造船 所ではじめてレーザ溶接が採用された画期的なものであ る.レーザ溶接の採用理由は, 客船建造では中厚板が採 用されるが, 美観の要求が厳しいためサブマージ溶接を 採用した場合，後工程での手直し費用が莫大となってい たためである.

マイヤー造船所が開発・適用しているサンドイッチパ ネルの応用も客船等を対象としたものであるが，これは 薄板を溶接変形の少ないレーザ溶接でサンドイッチ構造 とし軽量で剛性の高いパネルを製造するという新しい構 造化技術である。これは船舶の設計において軽量化が最 大の目的であるとともに軽量近代的な客船では乗客が集 まる劇場，レストランなどの部分では大きな金属の支持 構造が好まれないためサンドイッチパネルが有効となっ た。サンドイッチパネルを船舶に用いた場合のメリット は艦船への適用を検討した Bird および Furio ${ }^{5}$ により，軽 量, 高剛性, 断熱性, および酎火性能に優れることがす でに報告されているが, 変形が少なく目違いあわせ作業 が不要など生産性の向上にも寄与するとされている．同 社では，1995年より34隻のデッキやバルクヘッドなどに 適用され，その面積はすでに $25,000 \mathrm{~m}^{2}$ に達しているとの ことである、また，最近，内部に種々な材料を注入した 複合サンドイッチパネルのプロジェクト（SANDWICH） がはじめられ，更なる軽量化が達成されるとされている. サンドイッチパネルに代表される軽量化技術に対して, フィンランドでも数年にわたる軽量パネル開発のプロジ エクトが金属産業省を中心行なわれており，図 3 に示す ようなパネルをはじめ, 種々なパネル性能の向上に関す る開発が推進されている6. 今後，これらのサンドイッチ パネルは軽量化が要求される船舶以外の広い分野にも適 用が広がると思われる。

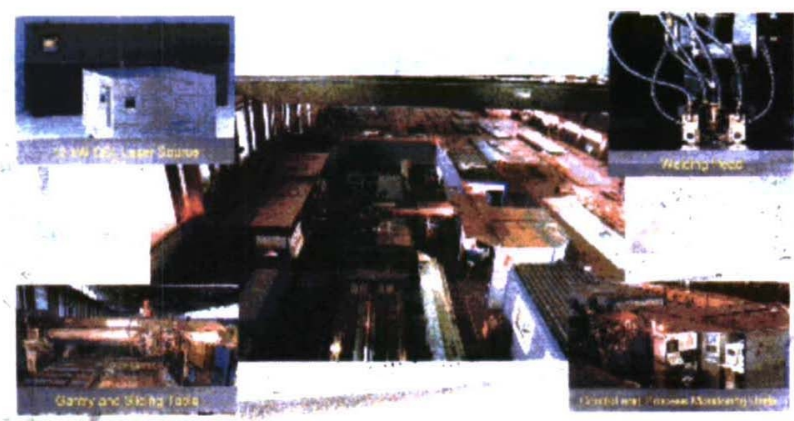

図2 マイヤ一造船所のパネル製造ライン

\section{2 レーザハイブリッド溶接}

レーザとアークのハイブリッド溶接はレーザ溶接の弱 点である開先精度の要求を䋧和できるメリットがある。 したがって，造船などの大型部材の溶接でつきまとう部 材精度の不足およびそれが原因となる表面欠陥などの防 止には溶着金属の添加が必須となる。現在ハイブリッド 溶接を実用化している造船所は先に述べたマイヤー造船 所と Blohm+Voss 造船所の 2 筒所であり，前者は部材を 機械加工し, 後者は無酸素切断により部材を加工してい るところが相違している，対象の船種はマイヤーが客船, 遊覧船およびガスタンカーであり Blohm+Voss は艦船で ある.ここでは, マイヤーからの詳しい報告5があるので 紹介する。ママイヤー造船所では増大する受注に対応する ため, 大型客船の納期を 10 ケ月から 6 ケ月とする必要が 生じ，実現のためのボトルネックがパネルとウエブの製 造ラインであることが分かった。この実現のため， 4 台 の $12 \mathrm{kWCO}_{2}$ レーザと MIG のハイブリッド溶接装置を開 発し，突合せ溶接装置とスチフナーを自動位置決めし， すみ肉溶接を行うことができる装置を構成している（図 4). 突合せ溶接ラインでは材料のハンドリンク， 機械加 工による開先加工および溶接が全自動で行なわれ $20 \mathrm{~m} \times$ $20 \mathrm{~m}$ のパネルが製造されている．スチフナーのすみ肉溶 接では, $20 \mathrm{~m}$ 長さのス千フナーの位置決めは $10 \mathrm{~min}$, パネル への溶接が $20 \mathrm{~min}$ のタクとして計画された.

レーザハイブリッド溶接が採用された理由は

・アーク溶接や単純なレーザ溶接より高速溶接ができ る.

・溶接ヘッド数が少なく，占有面積が少なくてすむ.

・溶接変形が少なく高精度品が生産できるため, 取り 付けや矯正時間が少なくなる.

・レーザハイブリッド継手の治金および疲労特性が優 れ，デッキの板厚を減少させ船体重量を軽減できる 可能性を持つ.
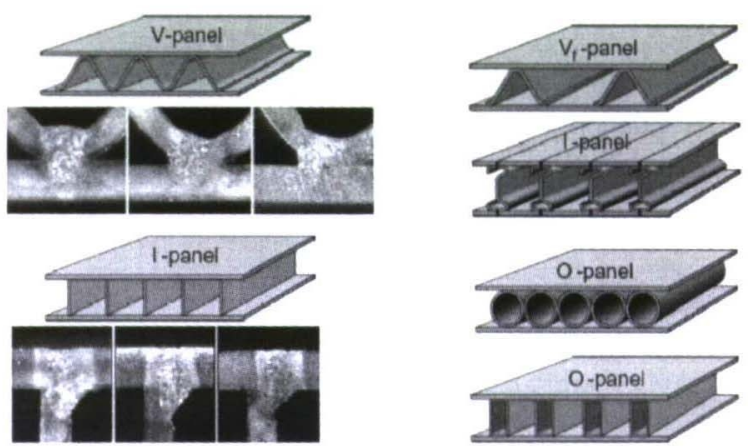

図3 フィンランドで検討されているサンドイッチパネルの一例
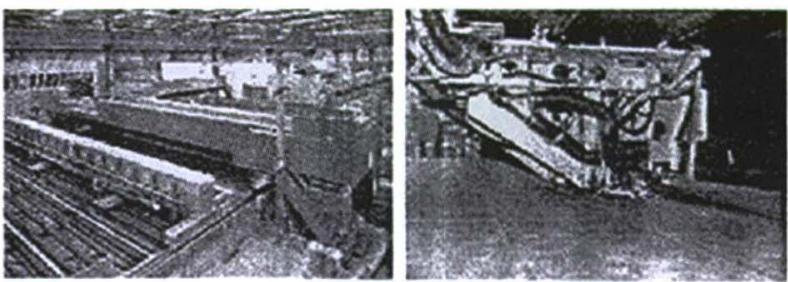

図4 レーザーハイブリッド溶接を採用したすみ内溶接装置外観 
・ $12 \mathrm{mmt}$ までの突合せ溶接とすみ肉溶接を 1 パスでで きる.（施工能力が高い）

・高精度が要求される他工程へ展開できる可能性があ げられている。

しかしながら，これを成就させるためには正確な開先 加工およびプロセス承認などの課題があった.

開先加工法については, プラズマ切断やレーザ切断, グラインディング法なども比較検討し, 最終的に機械加 工が選択されている。これは，プレート端部の熱影響が 小さいこと, 溶接プロセスの制御に重要なエッジの形状 のばらつきがないこと, 船級で要求されている面取りを 同じ装置でできる可能性を持つこと, 開先加工, 面取り および溶接を一つのマシンに組み込めること，およびレ ーザ切断機とレーザ溶接機の複合機より初期投資が少な いことから決定された.

プロセス承認作業では, 従来の溶接法に求められる硬 さ試験, 引張り試験, 衝撃試験, 曲げ試験, 十字引張り 試験などすべてに十分な性能を示したが, より信頼性の あるデー夕と製造時の試験量を低滅する目的で追加試験 が要求された。（Det Norske Veritas）。生産条件で製造さ れた試験体の疲労試験が承認機関で行われた。この結果 レーザハイブリッド溶接は2001年に完全承認され，実用 化されている.

日本では，造船の部材を機械加工することがコスト的 に成立しないとの判断が下されることが多いが，付加価 值が高い客船事業においては成立するところが興味深い.

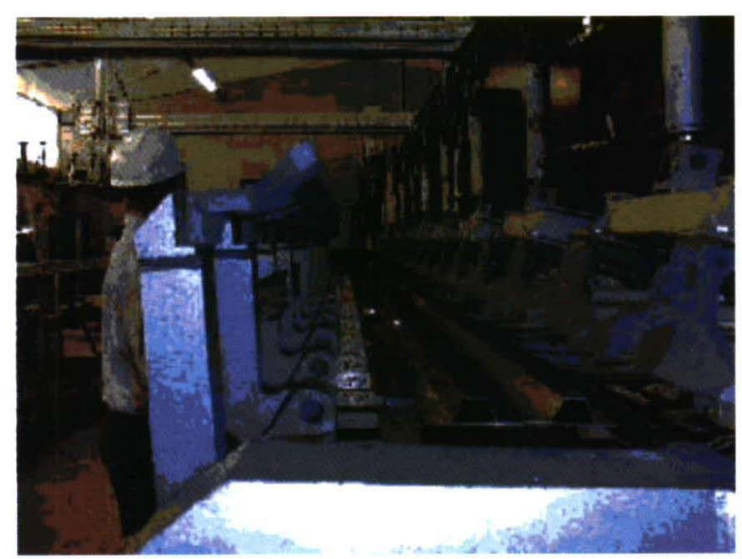

図5 ハイドマリン社のFSWによるプレファブパネルの 製造状況

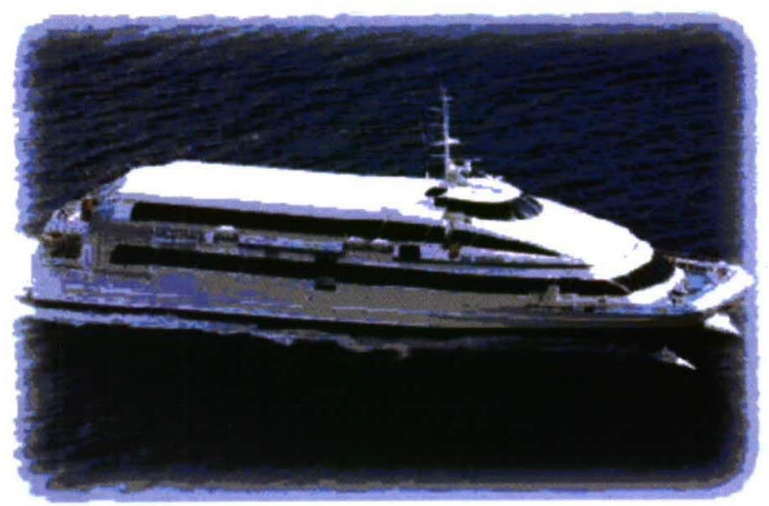

図6 FSWプレファイブパネルが採用された双胴船
マイヤー造船所の建造量はここ数年で増加しつづけてい るようであり，国際競争の激しい造船業ではこのような 技術を駆使する造船所が勝ち残ると考えられる。近い将 来国内にもこのような新しい生産技術を駆使した $21 \mathrm{C}$ 夕 イプの造船所が現れることを期待したい.

\subsection{FSW}

FSW は1991年に TWI で開発された技術であり，もっ とも新しい溶接法である. 特に，6000系のアルミニウム の溶接性が優れることから, 車両をはじめとする薄板分 野から適用がはじめられている。造船への適用はノルウ エーのハイドロマリン社, フェストランド造船所, およ びD N V（ノルウエー船級協会）の協力により達成され ている7. 図 5 はハイドロマリン社の FSW によるパネ ル製造状況を示す。ハイドロマリン社では $1.8 \mathrm{~mm}$ から $15 \mathrm{~mm}$ の6000系アルミ合金材パネルを製造し，累積溶接 長さは $150,000 \mathrm{~m}$ 以上に達している。 世界初の適用は, 同社により製造された 6082-T6の $6 \mathrm{~mm}^{8)}$ パネルがフェス トランド造船所へ輸送され, 図 6 に示す双胴船の上部構 造に適用したものである。なお，FSWの造船への応用に

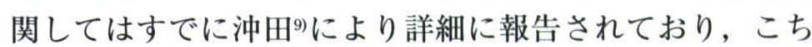
らをご参照願いたい.

残念ながら, 国内での船舶への適用例は未だないが, 最近川崎重工業（株）よりの超高速客船, 超高速カーフ エリーへの適用および LNG アルミタンクの製造へ適用し ていくことが報告10)され，近い将来実用化される見込みで ある・

\section{3. 重工分野におけるニュー溶接・接合 プロセスの適用}

重工分野は，広範囲にわたるが，造船に比べ溶接線長 は短いが板厚が厚く，適用材料の種類も多い。ここでは 重工分野として代表的な発電プラント機器を主体にニュ 一溶接・接合プロセス適用の現状と今後の展開をのべる.

\section{1 レーザ溶接}

発電プラント機器においては, 原子力及び火力分野を 主体に早くからレーザ溶接の高品質, 高能率性に着目し $\mathrm{CO}_{2}$ レーザ, YAGレーザの適用がはかられてきた.レー ザ溶接を構造化に生かす上での特徴としては, 低歪みで 入熱の低いプロセスであることから，熱影響が少なく， 高精度な構造物の製作が可能である. 従来, 出力の制約 からも高精度かつ品質要求の厳しい薄板分野への適用が 主流であった。

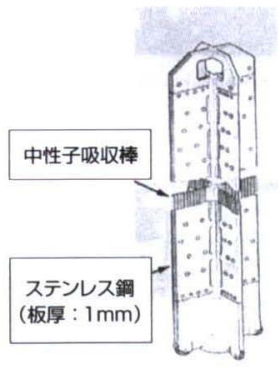

制御棒

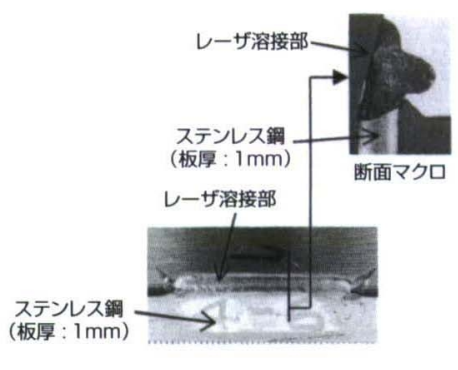

レーザ溶接部の外観と断面マクロ組織
図7レーザ溶接の原子力炬内機器への適用例 
四 7 は, レーザ溶接の原子力炉内機器への適用例を示 したものである. 炉内機器である制御棒は原子力圧力容 器内の核反応を制御する重要な機器であり, 板厚 $1 \mathrm{~mm}$ 程度のステンレス鋼の内側に中性子を吸収する材料が組 込まれており，このステンレス鋼は制御棒の中央で溶接 により接合されている構造となっている ${ }^{11)}$. 板厚が $1 \mathrm{~mm}$ 程度と非常に薄いことから溶接による熱変形を抑えるた めに TIG 溶接に代え，レーザ溶接の適用が四られている. レーザ溶接の採用により溶接変形を低減し精度の高い製 造を実現した例である. また, 図 8 も同様に炉内機器部 品へのレーザ溶接の適用例を示したものである. マグネ ットを収納するステンレス容器は溶接にて形成されるが, 溶接部近傍に強い磁界が存在するため, アーク溶接や電

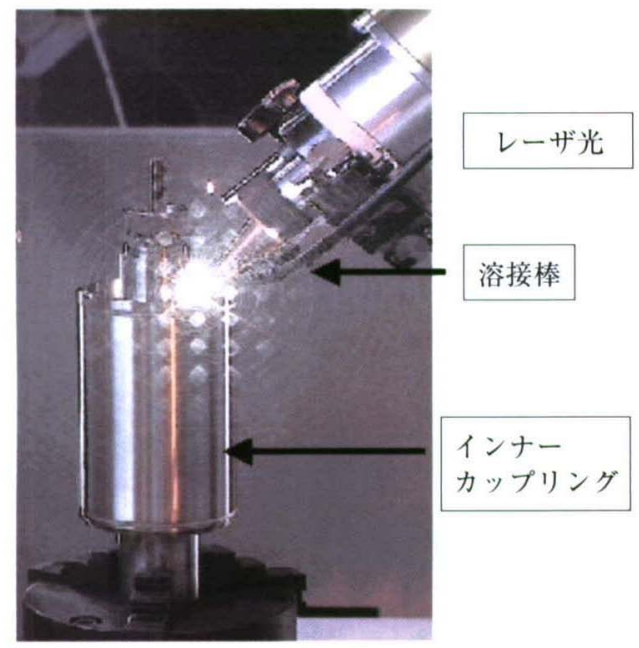

図8 炉内機器部品への適用例

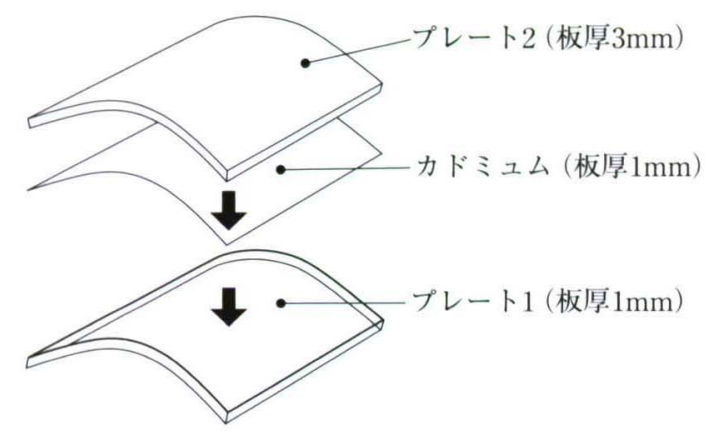

図9 中性子遮蔽体の構造

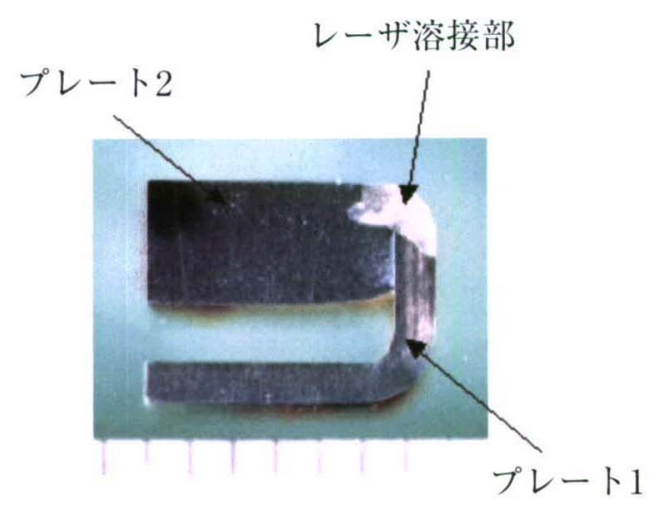

図10 中性子遮蔽体のレーザ溶接断面
子ビーム溶接などの溶接方法は適用することが難しい. そこで，磁力の影響を受けないレーザ光を利用したレー ザ溶接技術が適用されたものである.

図 9 に, 再処理機器への適用として, レーザ溶接の低 入熱である特徴をいかして構造化した例を示す。曲率半 径約 $1200 \mathrm{~mm}$ の箱状のプレート 1 （板厚 $1 \mathrm{mm）にカド}$ ミウム（板厚 $1 \mathrm{~mm}$ ）を入れて，更にプレート2（板厚 $3 \mathrm{~mm}$ ）でふたをして全周溶接する中性子遮蔽体にレーザ 溶接を適用したもので, 融点が約 $310^{\circ} \mathrm{C}$ と低いカドミウ ム板を溶融することなく, ステンレス鋼を完全に封止し, かつ溶接後の寸法精度が確保されている.レーザ溶接後 の溶接部の断面を図10に示すが, レーザ溶接特有の幅の 狭い溶接となっており，カドミウムに熱影響が及んでな いことが分かる.

一方, 火力プラント機器では, 精密部品であるガス夕 ービン燃焼器にレーザ加工が多く活用されている。これ らは，高温にて使用されることから， Ni 基合金や Co 基 合金などの難加工材である耐熱合金が多数使用されてい ることや高速, 高精度な製造技術の要求からレーザによ る孔あけ加工, 切断, 溶接が行われている. 図11に板厚 1.2 1.6 mm の薄板円筒体である燃焼器ライナーのレーザ 溶接の状況を示す.

また, 戝12に示すように, 核融合機器において, 真空 容器として超伝導コイルを内臓し盖を重ね溶接するパネ ル構造などが検討され，低入熱であるレーザ溶接が試験 されている.

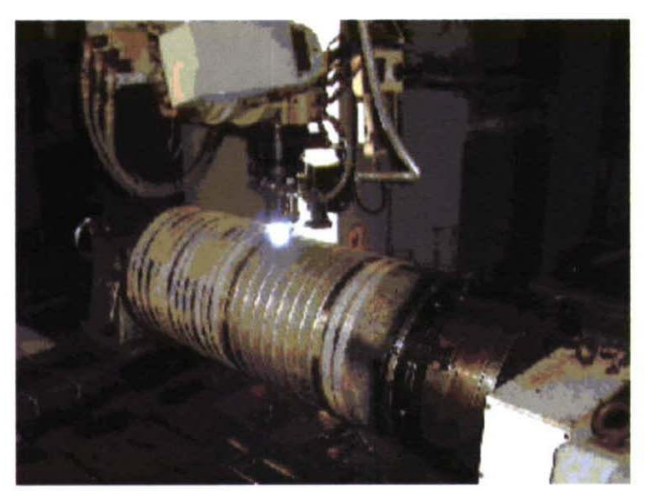

図11燃焼器ライナのレーザ溶接

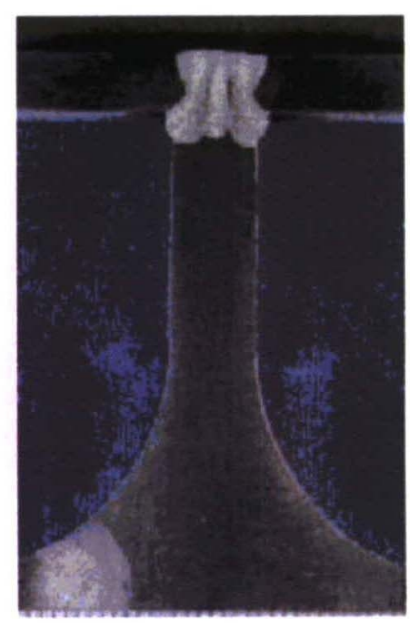

図12レーザ溶接の応用例 
以上のように，高精度かつ低入熱である特徵を生かし た構造化が, 薄板分野において幅広く適用されてきたが, 厚板複雑構造物への適用は, ミラー伝送などの問題から $\mathrm{CO}_{2}$ レーザでは限定されていた。これに対し，近年の光 ファイバによる伝送が可能な YAGレーザの高出力化がす すめられており, 厚板分野への適用が一挙に拡大される ものと期待できる.

\section{2 レーザハイブリッド溶接}

レーザハイブリッド溶接の利点は, 前に述べた通りで あるが，厚板でかつ開先精度が十分でない重工製品には， 非常に有効であり, 従来レーザ溶接の適用が困難であっ た部位へ適用拡大できる可能性が高い。図13は, $\mathrm{CO}_{2} レ$ ーザ・MIGハイブリッド溶接の例を示したもので， $6 \mathrm{KWCO}_{2}$ レーザにて突合せ溶接で 1 パス板厚 $15 \mathrm{~mm}$ 貫通 溶接が実現されている. また, ステンレス製圧力容器板 厚 $16 \mathrm{~mm}$ 角継手へ実用化され, 高品質溶接（低歪, ポロ シティ低減）が実現されている アークハイブリッド溶接のパイプライン配管溶接への適 用例も TWI から報告されており, 今後, 重工分野の中厚 板溶接の高能率化, 低歪による高品質化を狙ったレーザ ハイブリッド溶接 $\left(\mathrm{CO}_{2}\right.$ YAG レーザ・TIG/MIG アーク $)$ の適用推進が飛躍的にすすむと考えられる.

\subsection{FSW及び界面接合法}

現状, 重工分野の発電等のプラント機器における FSW の適用事例はほとんど報告されていない。これは，プラ ント機器の材料が, 鋼が主体であり, FSWが得意とする アルミ合金や銅の材料が少ないためである。近年, 片側 炭素鋼やステンレス鋼の FSW 技術が開発されてきてはい

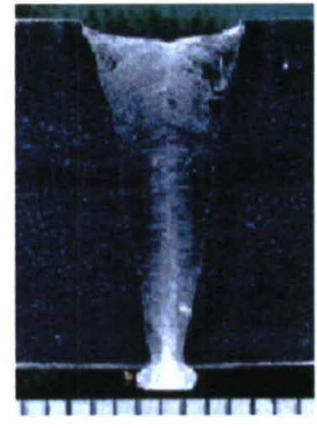

突合せ溶接 (1パス板厚 $15 \mathrm{~mm}$ 貫通溶接 $6 \mathrm{KwCO}_{2}$ レーザ+MIG

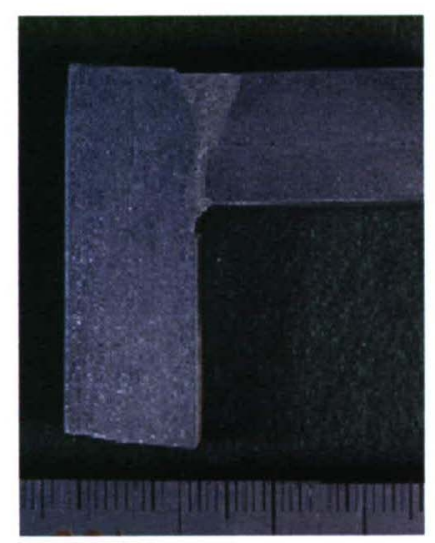

ステンレス厘力容器角継手への適用 (2パス：レーザ+レーザハイブリッ ド溶接）
図13 レーザ·MIGアークハイブリッド溶接の例
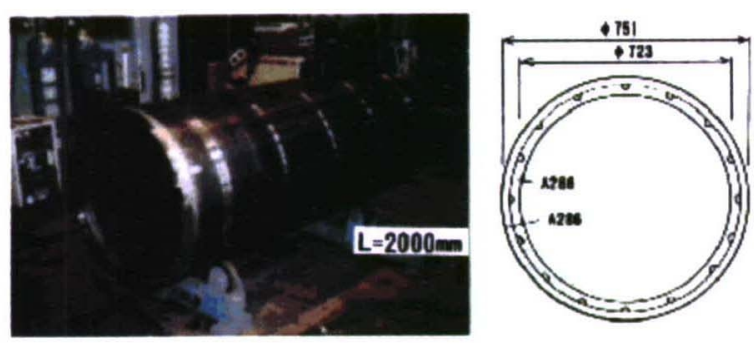

るが, アルミ合金への適用に比ベ, レーザやアーク溶接 をしのぐ特徴を見出し, 応用化できるかが課題である. 最近，銅やアルミ合金ではあるが，下板にあらかじめ溝 を設けておき蓋を FSW で接合することで内部に冷却用と なる水路を形成する集積配管等が報告されており ${ }^{13)}$, FSW の構造化への応用例として注目される。また，異種 金属の接合法としても有望であり, アーク等の融接で困 難な材料組み合わせの構造化が可能かもしれない.

一方, 界面接合法については, 拡散接合等の固相接合 が特殊材料や異材の接合として部品レベルで広く応用化 がはかられてきている，構造化に関しては，内面に冷却 溝を有する構造体やコルゲート構造の製作に液相拡散接 合や HIP 接合が適用されている. 図14は, 内部に冷却溝 を有した長さ $2000 \mathrm{~mm}$, 径 $750 \mathrm{~mm}$ の 2 層円筒構造の発 電機部品に HIP 接合を適用した例を示したものである ${ }^{14)}$. このように, 難溶接材の接合や大断面積を接合できる利 点があるものの, 装置の問題から製品寸法が制約をうけ ることから, 今後, 重工分野の大型部材への適用拡大に は, 局所的に施工が可能な界面接合法の開発が必要であ る.

\section{4.おわりに}

造船および重工業へのニュー溶接・接合プロセスの適 用の現状と今後の展開について述べた. 造船および重工 業では, 新しい溶接施工法を採用するには船級協会の承 認取得や各種法規に従った施工法の承認が必要であり, 実用化まで長期間を有するのが通常である.しかしなが ら，先の実用例などが示すように新しい施工法の信頼性 が確保できることが示されつつあり, 今後かなりの勢い で実務応用がなされてくるものと予想される. 今後, 関 係各位のご努力により新施工法が導入され, 溶接業界の 活性化と発展がすすむことを期待している.

\section{参 考 文 献}

1) 日本溶接接協会 HPL 委員会報告書

2) International conference, Exploitation of Laser Processing in Shipyards and Structural Steelwork, May, 1996, Glasgow, UK

3) Yamaoka: Welding technique, 2000, vol. 48. No11, 99-100

4) F. Roland: IIW International Conference, June 2002, Denmark

5) J. Bird: 20 March 1997, Southampton

6) J, Lasslia]: Private communication

7) O. T. Midling: Journal of light metal welding \& construction, vol. 59, (2001), Nol, 32-36.

8) K. Elik: Welding journal, September, 1997, 55-57

9) Okita: Journal of light metal welding \& construction, vol. 59, (2001), No10, 1-15

10) http://www.khi.co.jp/khi_news

11) 東芝レビューVol. 55, NO. 10 (2000)

12) K. Minami, et al: Laser-MIG Hyburid Welding Process for Stainless Steel, IIW Doc. No. XII-1704-02, 2002

13) NIKKEI MECHANICAL, 2001. 8, No. 563, P 44-45

14) 浅井 知他：成形·接合技術の実際, 本誌, 65-8 (1996), P 18-22

図 14 2層円筒構造を有した発電機部品のHIP接合 